ZOOLOGIA 28 (1): 112-114, February, 2011

doi: $10.1590 /$ S1984-46702011000100015

\title{
Description of the male of Pozonia bacillifera (Araneae: Araneidae)
}

\author{
Ivan Luiz Fiorini de Magalhães \& Adalberto J. Santos
}

\begin{abstract}
Departamento de Zoologia, Instituto de Ciências Biológicas, Universidade Federal de Minas Gerais. Avenida Antônio Carlos 6627,31270-901.Belo Horizonte,MG,Brazil.E-mail: ivanlfmagalhaes@yahoo.com.br; oxyopes@yahoo.com
\end{abstract}

\begin{abstract}
Pozonia Schenkel, 1953 is a genus of Neotropical orb-weaving spiders that currently includes four species, three of which are known only from females. In this paper, the male of Pozonia bacillifera (Simon, 1897) is described and illustrated for the first time, based on a specimen from Nova Lima, state of Minas Gerais, Brazil. It differs from the male of $P$. nigroventris (Bryant, 1936), the only other known male of the genus, in characters of the genitalia, such as the larger embolus and the smaller ventral lobe of the paracymbium, as well as in the shape of the sternum. This represents the first record of $P$. bacillifera for the region.
\end{abstract}

KEY WORDS. Neotropical region; spider; orb-weaver; taxonomy.

Pozonia Schenkel, 1953 is a small genus of orb-weaving spiders distributed all over Central and South America (PLATNICK 2010). When it was described, the genus contained only Pozonia cornuta Schenkel, 1953, the type species. The species was described based on juveniles only. In a recent revision, Levi (1993) considered it to be a nomen dubium. Nevertheless, he recognized the genus as valid and included three species in it, $P$. dromedaria (O.P.-Cambridge, 1893), transferred from Kaira O.P.Cambridge 1889, and P. bacillifera (Simon, 1897) and $P$. nigroventris (Bryant, 1936), both transferred from Wixia O.P.Cambridge, 1882. Most recently, a fourth species, P. andujari Alayón-García, 2007 was described by Alayón-García (2007) based on a female from the Dominican Republic. Except for $P$. nigroventris, which is known from males and females, all species currently included in the genus are known only from females. This situation prevents a better understanding of the phylogenetic position of the genus, since the male copulatory apparatus is one of the main sources of phylogenetic characters in spiders (SCharfF \& Coddington 1997, Levi 1999).

During a recent faunistic inventory in southeastern Brazil, a female of Pozonia bacillifera was collected along with a very similar, undescribed male specimen. The general similarity in body shape and coloration between the specimens, as well as the fact that both were collected in the same locality, led us to the conclusion that they are conspecific. Hence, in this study we describe and illustrate the male of $P$. bacillifera for the first time. Although this species is widely distributed in South America, this represents its first record from the state of Minas Gerais, and its northernmost and easternmost record from Brazil.

\section{MATERIAL AND METHODS}

Drawings were made using a Motic K400 stereoscopic microscope equipped with a camara lucida. The format of description follows Levi (1993) with the following modifications: the length of patellae and tibiae are given separately; femora from all legs were measured. All measurements are expressed in millimeters and were taken from the left side of the specimen, except where stated otherwise.

Specimens were deposited in the arachnological collection of Coleções Taxonômicas da Universidade Federal de Minas Gerais (UFMG, curator A.J. Santos).

\section{TAXONOMY}

\section{Pozonia bacillifera (Simon, 1897)}

Figs 1-5

Araneus (Vixia) bacillifer Simon, 1895: 819, fig. 870 (nomen nudum). Araneus (Vixia) bacillifer Simon, 1897: 475 (Two immature syntypes from Paraguay, deposited in the Musée National d'Histoire Naturelle, Paris, MNHN 8469, not examined). Aranea bacillifera, Strand 1916: 110.

Wixia bacillifera, Roewer 1942: 881; Bonnet 1959: 4828.

Pozonia bacillifera, Levi, 1993: 60, figs 11-14.

Diagnosis. Males of Pozonia bacillifera differ from those of P. nigroventris by the flat sternum, without a median knob (Fig. 3 ), and by several genitalic characters (Figs 4 and 5), as follow: the embolus of $P$. bacillifera is longer, has a pointed tip that covers part of the conductor and is visible in the unexpanded palp, while in P. nigroventris it is short and concealed beneath the terminal apophysis, not reaching the conductor; the terminal apophysis is straight, narrow and transparent, hardly visible above the embolus, while in P. nigroventris it is wide and hook-shaped; the paramedian apophysis has undulating margins, while in $P$. nigroventris it has straight margins; the median apophysis is longer than that of $P$. nigroventris (Fig. 4); and in retrolateral view, the pedipalps of both species differ by the ventral lobe of the paracymbium, which is small and finger-shaped in P. bacillifera and large and oval in P. nigroventris (Fig. 5). 


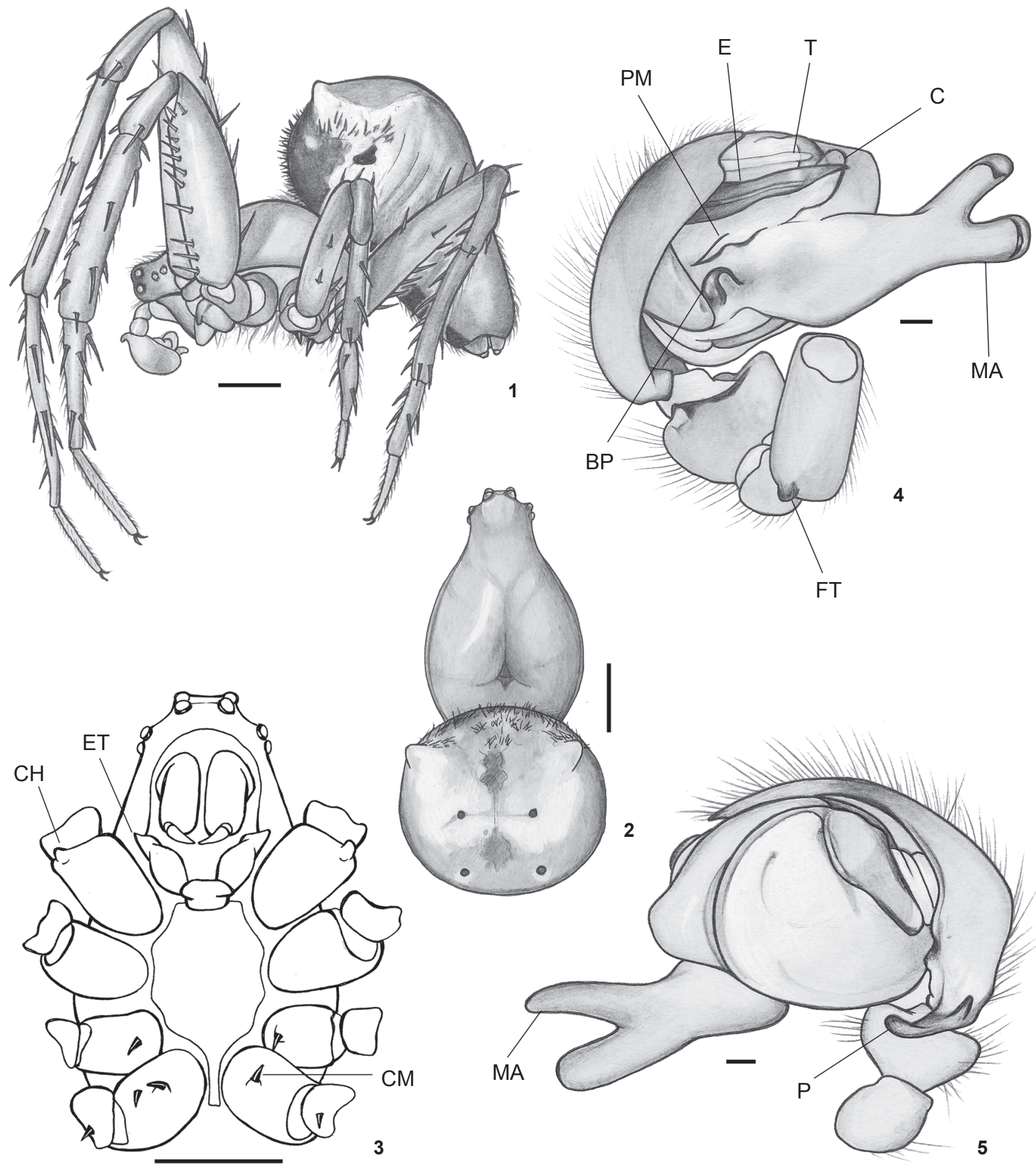

Figures 1-5. Pozonia bacillifera. (1-3) Male habitus: (1) lateral view; (2) dorsal view; (3) cephalothorax, ventral view. (4-5) Male left palp: (4) prolateral view; (5) retrolateral view. Scale bars: (1-2) $1.0 \mathrm{~mm}$, (3) $0.5 \mathrm{~mm}$, (4-5) $0.1 \mathrm{~mm}$.(BP) Basal projection of the median apophysis; (C) conductor; (CH) coxal hook; (CM) coxa and trochanter macrosetae; (E) embolus; (ET) endite tooth; (FT) femoral tubercle; (MA) median apophysis; (P) paracymbium; (PM) paramedian apophysis; (T) terminal apophysis. 
Description. Male (UFMG 2479). Carapace yellowish brown, with cephalic region darker and much narrower than thoracic region (Fig. 2). Chelicerae and sternum pale yellow. Endites and labium pale yellow, with conspicuous white borders. Legs pale yellow to light brown, darker than carapace. Dorsum of abdomen white, sides yellowish gray, venter dark brown. Abdomen with many dark, spindle-shaped setae on its anterior surface, a pair of tiny, dorsal tubercles and a pair of black pigmented patches on the sides (Figs 1 and 2). Eye diameters relative to the anterior median eyes: posterior median 0.85 , anterior lateral 0.71 , posterior lateral 0.71 . Anterior median eyes 2.3 diameters apart. Anterior margin of the median ocular quadrangle as wide as the posterior. Height of clypeus equal to 1 diameter of anterior median eyes. Sternum flat, without a median knob. First coxa with a ventral hook (Figs 1 and 3), second femur with a corresponding prolateral groove. Second tibia not branched, with many strong macrosetae on its prolateral face. Third and fourth coxae and fourth trochanter with ventral, strong macrosetae (Fig. 3). All coxae and trochanters with long, conspicuous, pale yellow hairs (Fig. 1). Total length 6.3. Carapace 3.48 long, 2.47 wide at its widest point, 0.99 wide behind the eyes. Length of first femur, 4.6; patella, 1.5; tibia, 3.95; metatarsus, 3.35 ; tarsus 1.45 . Second femur, 3.85; patella, 1.28; right tibia, 3.03. Third femur, 2.47; patella, 1.07; tibia, 1.62. Fourth femur, 3.8; patella, 1.37; tibia 2.6. Palp as a whole appears lightly sclerotized. Terminal apophysis narrow and transparent. Embolus flat, wide and pointed. Conductor has a lobe partially covered by the tip of the embolus, and an attached paramedian apophysis pointing towards the radix. Median apophysis has two long and slender branches and a basal projection. Cymbium has a conspicuous dent on the distal margin, near the base of the embolus (Fig. 4). Paracymbium with two simple, finger-shaped lobes (Fig. 5).

Material examined. BraziL, Minas Gerais: Nova Lima, Reserva Particular do Patrimônio Natural Mata Samuel de Paula $\left(20^{\circ} 0^{\prime}\right.$ S, $43^{\circ} 52^{\prime}$ W), J.P.P. Pena-Barbosa et al. leg., 04.VII.2007, 1 male (UFMG 2479); ditto, 01.V.2007, 1 female (UFMG 2480).

Remarks. Although they were not collected together, the male was matched to females of $P$. bacillifera because they are morphologically similar and were collected in the same area. In addition, this is the only species of Pozonia known to occur in southeastern Brazil. Levi $(1993,2002)$ stated that the median knob found on the sternum of males of $P$. nigroventris is synapomorphic and diagnostic for Pozonia. As the male of $P$. bacillifera has a flat sternum, we have considered that the sternum median knob is autapomorphic and diagnostic for $P$. nigroventris only, and not for the entire genus, at least until males of the remaining species are found and described.

Natural history. The specimens examined were collected in the understory foliage using beating trays and through nocturnal manual collecting at a patch of semi-deciduous Atlantic forest in southeastern Brazil. Adult specimens were obtained only during the dry season.

\section{ACKNOWLEDGMENTS}

We thank Anglo Gold Ashanti for authorizing field work in its private natural reserve and for financial support for the expeditions, and the staff of Laboratório de Aracnologia (UFMG) for help in the field. We also acknowledge two anonymous referees for suggestions on the manuscript. This study was financially supported by a PROBIC/FAPEMIG scholarship to I.L.F. Magalhães and by grants from CNPQ (472976/2008-7 and 300498/2009-8) and Instituto Nacional de Ciência e Tecnologia dos Hymenoptera Parasitóides da Região Sudeste Brasileira (http://www.hympar.ufscar.br) to A.J. Santos.

\section{LITERATURE CITED}

Alayón-García, G. 2007. Especie nueva de Pozonia (Araneae: Araneidae) para República Dominicana. Solenodon 6: 41-44.

Bonnet, P. 1959. Bibliographia Araneorum. Toulouse, Douladore, vol. 2, p. 4231-5058.

Levi, H.W. 1993. The Neotropical orb-weaving spiders of the genera Wixia, Pozonia, and Ocrepeira (Araneae: Araneidae). Bulletin of the Museum of Comparative Zoology 153: 47-141.

Levi, H.W. 1999. The Neotropical and Mexican orb weavers of the genera Cyclosa and Allocyclosa (Araneae: Araneidae). Bulletin of the Museum of Comparative Zoology 155: 299-379.

Levi, H.W. 2002. Keys to the genera of araneid orbweavers (Araneae, Araneidae) of the Americas. Journal of Arachnology 30: 527562.

Platnick, N.I. 2010. The World Spider Catalog. New York, American Museum of Natural History, version 11.0. Available online at: http://research.amnh.org/iz/spiders/catalog [Accessed: 03.XI.2010].

Roewer, C.F. 1942. Katalog der Araneae von 1758 bis 1940. Brussels, Institut Royal des Sciences Naturelle de Belgique, vol. 1, p. 1-1040.

SIMON, E. 1895. Histoire Naturelle des Araignées. Paris, Librarie Encyclopédique de Roret, vol. 1, p. 1-1084.

Simon, E. 1897. Études arachnologiques. 27e Mémoire. XLII. Descriptions d'espèces nouvelles de l'ordre des Araneae. Annales de la Societé Entomologique de France 65: 465-510.

Scharf, N. \& J.A. CodDington. 1997. A phylogenetic analysis of the orb-weaving spider family Araneidae (Arachnida, Araneae). Zoological Journal of the Linnean Society 120: 355-434.

STRAND, E. 1916. Systematische-faunistiche Studien über paläarktische, afrikanische und amerikanische Spinnen des Senckenbergischen Museums. Archiv für Naturgeschichte 81 (A9): 1-153.

Submitted: 13.VIII.2010; Accepted: 01.I.2011. Editorial responsibility: Antonio D. Brescovit 